\title{
Argentina-Import Measures: How a Porsche is worth Peanuts
}

\author{
PAOLA CONCONI \\ ECARES, ULB and CEPR \\ HARM SCHEPEL \\ Brussels School of International Studies, University of Kent
}

\begin{abstract}
The dispute Argentina-Measures Affecting the Importation of Goods concerns a series of measures imposed by Argentine authorities on economic operators as a condition for obtaining import licenses. These measures were introduced with the goal of advancing the Argentine government's stated policies of re-industrialization, import substitution, and elimination of trade balance deficits. From a legal point of view, the least interesting feature of the dispute was the substantive compatibility of these measures with Article XI:1 GATT as they clearly constituted import restrictions. Identifying and classifying the measures involved, however, proved more challenging: based on vague policy guidelines, devoid of any legal basis, and consisting largely of wholly discretionary ad hoc action by the authorities, clouded in confidential obscurity, the measures escaped familiar categories and distinctions of WTO law. From an economic perspective, although Argentina's measures appear to have had no impact on its overall imports, they imposed large costs on foreign companies, as well as on Argentine importers and consumers.
\end{abstract}

\section{Introduction}

In August 2012, the United States, European Union, and Japan requested separate consultations with Argentina concerning certain measures imposed on the importation of goods (Argentina-Import Measures). ${ }^{1}$ The dispute involved two measures:

1. Since February 2012, all imports into Argentina were subject to a pre-registration and pre-approval regime, called the Advance Sworn Import Declaration or 'Declaración Jurada Anticipada de Importación' (DJAI).

2. Since 2009, Argentina has imposed on importers and other economic operators one or more of the following restrictive trade-related requirements (TRRs):

Email: pconconi@ulb.ac.be

1 Panel Reports, Argentina-Measures Affecting the Importation of Goods, DS438, DS444, DS445. 
(a) Offsetting the value of their imports with, at least, an equivalent value of exports (one-to-one requirement);

(b) Reaching a certain level of local content in their domestic production (local content requirement);

(c) Limiting their imports, either in volume or in value (import reduction requirement);

(d) Making investments in Argentina (investment requirement);

(e) Refraining from repatriating profits from Argentina (non-repatriation requirement).

According to the complainants, these measures were part of Argentina 'managed trade' policy ('comercio administrado'), meant to advance the Argentine government's stated policies of re-industrialization, import substitution, and elimination of trade balance deficits. ${ }^{2}$ The complainants argued that DJAI is inconsistent with Article XI:1 of the GATT, because it constitutes a non-automatic import licensing measure, which creates uncertainty as to whether importation will be allowed, does not allow companies to import as much as they desire, and imposes a significant burden on importation. ${ }^{3}$ Concerning the TRRs, the complainants argued that Argentine authorities systematically impose them as a condition for obtaining the import licenses, failing to issue DJAI approvals in a timely manner and withholding DJAI approvals from firms that have declined to comply with the restrictions. They described the TRRs as a single measure, which restricts the automatic importation of goods and is thus inconsistent with Article XI:1. The local content requirement is also inconsistent with Article III:4 of the GATT.

Argentina rejected the complainants' claims. It argued that the DJAI procedure is a customs or import formality subject to Article VIII of the GATT and therefore not subject to Article XI:1 of the GATT or the Import Licensing Agreement. With respect to the TRRs, it argued with the Panel that the complainants did not produce evidence of the existence of a single 'overarching' measure with general and prospective application. In Argentina's view, even if the Panel were to accept the complainants' characterization of the evidence relating to the TRRs, at most

2 'The Argentine government stated that import substitution is a state policy and one of the main tools to reindustrialize the country. It has referred to this objective in numerous statements, as well as in its Industrial Strategic Plan 2020. The President of Argentina stated in October 2011 that the final objective of the Government is to domestically substitute around 45\% of imports'. Panel Reports, Argentina-Import Measures, para. 6.197.

3 Non-automatic import licenses are not WTO compatible, unless they are justified by certain exceptions under WTO rules. Article XI (General Elimination of Quantitative Restrictions) of the GATT states (excerpts): No prohibitions or restrictions other than duties, taxes or other charges, whether made effective through quotas, import or export licenses or other measures, shall be instituted or maintained by any contracting party on the importation of any product of the territory of any other contracting party or on the exportation or sale for export of any product destined for the territory of any other contracting party. 
this might indicate the existence of a series of individual one-off and isolated actions that concern a limited number of individual economic operators in a limited number of sectors, whose content varies considerably and lacks general and prospective application.

On 15 January 2015, the Appellate Body issued a ruling in favor of the United States, the European Union, and Japan, upholding the Panel reports circulated on 22 August 2014. The Appellate Body found that Argentina's import licensing requirement and the TRRs are inconsistent with Article XI:1 of the GATT 1994 as restrictions on the importation of goods.

This dispute reflected increasingly tense relations between Argentina and its main trading partners. In 2008, President Cristina Fernandez de Kirchner stunned investors when she nationalized private pension funds at the height of the global financial crisis. She also renationalized the country's flagship airline, Aerolíneas Argentinas. In April 2012, she introduced a bill for the partial renationalization of YPF, a leading energy company controlled by Spain's Repsol, on the grounds that energy is a 'vital resource'. Such measures were popular with ordinary Argentines, many of whom blamed free-market policies such as the privatizations of the 1990s for the economic crisis and subsequent debt default of 2001-2002. However, they worsened the relations with the EU and other trading partners. When filing the complaint against Argentina in May 2012, EU Trade Commissioner Karel De Gucht stressed that 'the trade and investment climate in Argentina is clearly getting worse'. 'While the EU's WTO action on import measures is separate from and independent to Argentina's Repsol case, the EU is responding to Argentina's broader and systematic economic restrictions ... The Repsol case, like the trade restrictive import measures the EU challenges today, is rather to be seen as an expression of the same worrying policy pursued by Argentina.' 4

The dispute comes on the heels of a raft of investment Treaty arbitration cases arising out of the Argentine crisis in the early 2000s and the associated devaluation of the peso, ${ }^{5}$ and indeed in the midst of litigation in New York and elsewhere initiated by disgruntled bondholders, ${ }^{6}$ the dispute should also be seen in the context of the wider question of the compatibility of 'managed capitalism' with the normative framework of international economic law.

This article reflects on the Argentina-Measures Affecting the Importation of Goods dispute from a legal and economic perspective. In Section 2, we discuss some legal aspects of the Panel's and Appellate Body's ruling. The dispute pushes the boundaries of classic trade law: rather than a piece of legislation or its implementation, the 'measure' at issue here involved a number of unwritten

4 See 'European Union Challenges Argentina's Import Curbs at WTO', Bloomberg, 25 May 2012. See more generally Baracat et al. (2015).

5 See Alvarez and Khamsi (2009).

6 See, for example, Alfaro (2015). 
requirements imposed on individual economic operators in pursuance of a widely publicised but vague policy of 'managed trade'. In Section 3, we examine the dispute from an economic perspective, providing examples of the different TRRs imposed on importers and economic operators, looking at the evolution Argentina' imports from the complaining parties, and discussing the economic costs of the TRRs for foreign and domestic companies, as well as for Argentine consumers. Section 4 concludes.

\section{Legal analysis}

That the substantive conditions imposed on importers by the Argentine authorities amounted to restrictions under Article XI:1 GATT was hardly in doubt. The important legal issues in the reports revolve around the question of how to identify and classify the challenged measures. The authorities acted in pursuance of an unwritten general policy of 'managed trade' without a precise legal basis in seemingly unfettered discretion: where the restriction is largely a function of the absence of rules, familiar distinctions in WTO law between a rule and its 'application' or its 'administration' are not obviously very useful.

\subsection{Evidence of the restrictions}

At the heart of the 'TRRs measure' was a long list of 'agreements' between the authorities and individual importers and economic operators striking deals involving one or more of the five requirements listed above. How exactly these commitments were obtained is far from clear. In some cases, they seem to have been extracted from importers as conditions for obtaining approval under the DJAI procedure, ${ }^{7}$ but in others even the cover of a formal framework was dispensed with. Complainants made much of the fact that officials expressed their exigencies generally orally in face-to-face meetings, with apparent wide-ranging discretion and entirely ad hoc. Adding some color to its description, Japan cited reports of threats and intimidation, including an incident where the Secretary 'once put a handgun on a conference table during a meeting to show he meant business'. ${ }^{8}$ What does seem clear is that the commitments, once agreed upon, were generally put in writing, either in unilateral letters of importers addressed to the government or in agreements between companies and the authorities. But very few people have ever seen any of these documents.

Argentina was of the opinion it was under no duty to help build the case against itself and thus declined the invitation of the Panel to produce the documents. The only evidence presented by complainants in this regard were statements by notaries

7 Panel Reports, Argentina-Import Measures, para. 6.395.

8 First part of the executive summary of the arguments of Japan, Panel Reports, Argentina-Import Measures, Addendum 1, Annex B5, para. 20. 
that they had seen some of the agreements. Even though complainants - especially the EU - did not deny having such documents in their possession, they refused to hand them over to the Panel on the grounds that the companies involved did not grant permission to do so out of fear of retaliation. The Panel went out of its way to devise a special procedure involving a Geneva notary, but that attempt was abandoned. ${ }^{9}$ Instead, complainants brought as evidence - and the Panel by and large accepted as evidence - a whole raft of news-clippings, press releases, reported statements by government and company officials, websites, and other public source material showing that clearly something was going on.

It may seem odd that complainants were so reluctant on the evidentiary front. As mentioned before and further discussed in Section 3.1, they indicated that importers and economic operators had not authorized them to provide copies of the agreements with Argentine authorities because of fear of retaliation. We can only speculate as to the identity of the economic operators involved and the information contained in these documents that were not publicly available and entered as evidence in hundreds of exhibits. In any event, Argentina did not bother to deny the existence of the commitments, or to argue that these were simply voluntary agreements between consenting parties. It stands to reason, though, that Argentina was quite happy to have complainants pursue hundreds of separate claims, and it is clear that complainants were satisfied with showing something was going on that they could argue formed part of a broader, single measure.

Only the EU hedged its bets, and requested findings on 23 specified individual measures. Here, the Panel reached the limits of its patience. Willing to accept websites and press releases as evidence of a widespread practice of extracting commitments, it refused to accept such sources as sufficient to identify 'measures at issue' under Article 6.2 DSU: 'A Panel request that requires a reader to access information from a website and deduce from that information what the challenged measures are, cannot be said to be "sufficiently precise".'10 In the only reversal of the Panel's findings in this case, the Appellate Body had no difficulty finding information about (a) the involvement of the Argentine government; (b) the particular economic operator, sector, or industry concerned; and (c) the specific TRRs allegedly imposed. ${ }^{11}$ It would have been interesting to see the AB complete the legal analysis and render a decision on the compatibility of each of the 23 cases with the GATT, but since the EU's appeal on the matter was conditional on the rejection of the claim about the 'single measure', the $\mathrm{AB}$ could dispense with this.

9 Panel Reports, Argentina-Import Measures, para. 1.28.

10 Panel, Argentina-Import Measures, Second Preliminary Ruling, Addendum 1, Annex D2, para. 4.37 .

11 AB Reports, Argentina-Import Measures, para. 5.81. 


\subsection{One measure or hundreds of measures?}

Challenging any of the five individual requirements or challenging combinations of these requirements imposed on individual companies would not have been easy or very useful. ${ }^{12}$ Neither would be challenging a general broad and unwritten policy of 'managed trade', aimed at import substitution and reducing trade deficits. ${ }^{13}$ The task at hand for complainants was to devise a way of framing the ensemble as a challengeable 'single measure'. It might be worth noting how the complainants chose to characterize the measure. For the US, it consisted of a 'decision by highlevel officials to require commitments of importers' as a 'prior condition for permission to import goods'. ${ }^{14}$ The EU described the 'overarching measure' as a 'systemic approach adopted by Argentina to prohibit or restrict the importation of products and/or the use of imported products in Argentina with a view to achieving its trade balancing and import substitution objectives'. ${ }^{15}$ Japan, for its part, spoke of 'an unwritten policy or practice, as confirmed by the systematic application of the measure'. ${ }^{16}$

For Argentina, it was clear that, whether they framed it as a 'decision', a 'practice', a 'policy' or an 'approach', complainants were mounting a claim against a non-existent measure 'as such'. The EU and the US strenuously denied bringing an 'as such' claim. Japan, on the other hand, explicitly did bring an 'as such' claim, in the alternative.

It is part of the GATT acquis that Members can bring claims against measures containing rules or norms 'as such', independently of whether and how these rules or norms are applied in particular instances. The purpose of this is for WTO-inconsistent behavior to be eliminated at its root, thus avoiding a multiplicity of litigation against instances of application of measures. ${ }^{17}$ In US-Zeroing (EC), the $\mathrm{AB}$ allowed an 'as such' claim against an unwritten rule or norm, but only if the measure at issue had 'general and prospective application'. ${ }^{18}$ Argentina argued that this was the appropriate legal standard for determining the existence of the alleged 'single measure', something both the Panel and the AB denied, emphasizing

12 As the EU put it, 'challenging each of the TRR requirements as isolated cases will not get rid of the problem faced by the EU industry'. Second part of the executive summary of the arguments of the EU, Panel, Argentina-Import Measures, Addendum 1, Annex B2, para. 33.

13 Argentina noted that '[i]t would appear that the complainants have filed their claims as a warning to developing countries that dare to decide their own policies and take measures independently of those dictated by the developed countries'. First part of the executive summary of the arguments of Argentina, Panel, Argentina-Import Measures, Addendum 1, Annex B7, para. 11.

14 AB Reports, Argentina-Import Measures, para. 5.115.

15 Ibid., para. 5.113.

16 Ibid., para. 5.96 .

17 Ibid., para. 5.101, with reference to Appellate Body Report, United States - Sunset Review of AntiDumping Duties on Corrosion-Resistant Carbon Steel Flat Products from Japan, WT/DS244/AB/R, para. 82 (US-Corrosion-Resistant Steel Sunset Review).

18 Appellate Body Report, United States- Laws, Regulations and Methodology for Calculating Dumping Margins (Zeroing), WT/DS294/AB/R, para. 198 (US-Zeroing (EC)). 
that the universe of challengeable measures is not defined and limited by the distinction between 'as such' and 'as applied' ${ }^{19}$ All that is really expected of complaining Members, then, is that they substantiate with evidence and argument that the 'measure', any kind of measure, exists as they describe it. The confusing thing about this is that complainants in this case described the 'single measure' as 'having certain attributes of generality and prospectiveness'. 20

The Panel decided to split the analysis in two separate parts. It first considered the joint claims against the sui generis 'single measure'. Here, it was concerned mostly with connecting the different TRRs into a whole bigger than (and distinct from) its parts, and smaller than (and distinct from) the overall Argentine policy of 'managed trade'. Truth be told, the Panel made a bit of a mess of it, but the AB undertook a valiant rescue mission and 'restated' the Panel's findings as follows:

5.130. In our view, the Panel's analysis of the content of the TRRs measure, including the analysis of how the individual components of the single measure apply and operate together as part of that whole, cannot be separated and considered in isolation from the Panel's detailed analysis of the contents of the individual TRRs in the preceding subsubsection of its Reports. We understand the Panel to say that the combined application and operation of the individual TRRs is an important part of the TRRs measure with distinct content. In particular, we understand the Panel to conclude that the precise content of the TRRs measure coincides neither with the content of the individual TRRs nor with that of the 'managed trade' policy or its underlying objectives (import substitution and deficit reduction). Rather, the content of the single measure consists of the combined operation of the individual TRRs as one of the tools that Argentina uses to implement the 'managed trade' policy. This content is distinct both from that of each TRR - which, taken individually, may not be apt to implement the 'managed trade' policy - and from the content of the 'managed trade' policy itself. We further observe that Argentina's managed trade policy encompasses elements other than those objectives that the Panel identified as relevant to the TRRs measure, and, in any event, we do not understand the Panel to have treated Argentina's 'managed trade' policy itself as a measure at issue in these disputes.

This is, frankly, pure sophistry. It tries to spirit into autonomous existence something consisting of two parts, which can only be defined in reference to each other. But from the contents of the various TRRs there is no way of knowing what 'managed trade' might be: but from the policy of 'managed trade', it would be very hard to make any sense of something as preposterous as forcing a car importer to export 'one-on-one' enough peanuts to achieve an overall trade

19 AB Reports, Argentina-Import Measures, paras. 5.105 and 5.106 cited the Appellate Body Reports, EC and Certain Member States - Large Civil Aircraft, WT/DS316/AB/R (a subsidy 'programme') and United States-Continued Existence and Application of Zeroing Methodology, WT/DS350/AB/R ('ongoing conduct') as examples of measures that fall outside these categories.

20 AB Reports, Argentina-Import Measures, para. 5.116. 
balance at the firm level. The Panel then went on to analyze Japan's 'as such' claim separately, concentrating on the question of whether the measure was of 'general and prospective application', which it answered affirmatively.

The $\mathrm{AB}$ was more than a little puzzled by this exercise. ${ }^{21}$ As it reconstructed the Panel's conclusions on the joint claims, the Panel had already found the 'TRR measure' to be of systemic application - as opposed to sporadic, unrelated applications of individual TRRs, and had already found the measure to be of 'continuous' application - in the sense that it would be applied in the future until the underlying policy would be modified or withdrawn. ${ }^{22}$ The $A B$, rightly, dismissed any suggestion that 'systematic' in this context meant anything different from 'general', or that 'continuous', in this context, was distinct from 'prospective'. In the AB's view, then, the Panel's findings under the 'as such' claim added nothing new to the analysis under the joint claims - where the Panel had already found the 'TRR measure' to be inconsistent with Articles III:4 and XI:1 GATT.

Given that Argentina's appeal was limited to the procedural grounds of Article 11 of the DSU, the AB did not actually formally reverse the Panel's findings on this issue. But it did note, rather harshly, that it 'did not wish to been seen to be endorsing' the Panel's findings. ${ }^{23}$ It is perfectly clear from the AB's report that 'as such' claims can be brought as such only against measures containing 'rules or norms', ${ }^{24}$ something the TRR measure decidedly was not. This is surely right in principle, however difficult the distinction between 'rules or norms', on the one hand, and a 'policy', on the other, may turn out to be. A claim against a policy, then, requires evidence of its application. The $\mathrm{AB}$ also seems to demand a showing that the combination of policy and application is distinct from either in content, a requirement that does not obviously make a lot of sense and seems formalistic to a fault. To say that statements of policy cannot be challenged unless there is evidence of its application, and that instances of application can only be challenged collectively as a single measure if there is evidence of a deliberate policy driving them would seem quite sufficient to avoid abuse of the DSU - the demand that each has a content that is distinct from the other only invites artificial reasoning.

\subsection{Formality, procedure or substance?}

The DJAI procedure did have a legal basis, and was, on its face, rather modern in its implementation. Importers were required to go online and supply rather basic information about planned transactions. If all went well, the information was reviewed and deemed acceptable by relevant agencies and the DJAI moved from

21 Ibid., para. 5.183 .

22 Ibid., paras. 5.142 and 5.143 .

23 Ibid., para. 5.181.

24 Ibid., paras. 5.116 and 5.183 . 
'registered' status to the much coveted 'exit' status which gave importers a window of 180 days to do their business. The trouble started when agencies decided to submit 'observations', in which case 'exit' status could only be reached by these 'observations' being lifted.

It seems that importers had no way of knowing beforehand which agencies could submit observations or even, after the fact, of identifying which agencies had in fact submitted observations. The legislation also failed to put any discernable limits to the substance of these observations, which in practice seems to have ranged from requests for additional information to de facto impositions of the TRRs as a condition for observations being lifted.

The Panel analysed the DJAI as one single measure under Article XI:1 GATT and held it to constitute an import restriction both for its direct effects on market access, and for the indirect effects of creating uncertainty, of not allowing operators to import as much as they would want to, and for conditioning imports on export performance. ${ }^{25}$ Even if the $\mathrm{AB}$ endorsed these findings as such, ${ }^{26}$ it did express some perplexity on how the Panel arrived at the analysis under Article XI:1 GATT.

At issue were two distinct concerns: first, Argentina claimed that the DJAI should be considered a 'customs formality' under Article VIII, which, it claimed, excluded it and from the scope of Article XI:1 altogether. Second, in case that argument failed, Argentina urged the panel to consider the DJAI under the Import Licensing Agreement first, on the theory that the latter constituted lex specialis in relation to Article XI:1 GATT. The Panel dismissed both of these arguments on similar reasoning: obviously convinced that the DJAI, whatever else it could be considered to be, was an import restriction, it decided to examine the DJAI under Article XI:1 GATT both irrespective of whether it constituted a customs formality subject to the obligations in Article VIII, ${ }^{27}$ and irrespective of whether it constituted an import licensing procedure subject to the obligations of the ILA. ${ }^{28}$

Under the Article VIII argument, the Panel's approach is logically sound. Argentina's argument was premised on Articles VIII and XI GATT being mutually exclusive: both Panel and AB, rightly, rejected that premise, and held that the scope of the two provisions overlaps. ${ }^{29}$ As such, the conclusion that the DJAI could be analyzed under Article XI:1 GATT, regardless of whether it fell within the scope of Article VIII, is unobjectionable.

Under the lex specialis argument about the ILA, however, the issue is more problematic. Two leading principles, pronounced most prominently in EC-Bananas III, govern the relationship between the ILA and the GATT. First, the ILA deals with

25 Ibid., para. 6.479 .

26 AB Reports, Argentina-Import Measures, para. 5.288.

27 Panel Reports, Argentina-Import Measures, para. 6.444.

28 Ibid., paras. 6.363 and 6.448 .

29 Ibid., para. 6.443, and AB Reports, Argentina-Import Measures, para. 5.237. 
the administration of import licensing rules, not with these rules per se. ${ }^{30}$ Second, the relationship is subject to the general order-of-analysis principle in WTO law, which requires Panels to start from the more specific, detailed provisions of Annex 1A agreements before delving into the GATT. ${ }^{31}$ The Panel latched on to the first. Spurred on by the way that complainants framed their challenge of the DJAI - 'not so much as a set of import licensing procedures than as a restriction on imports imposed through import licensing' 32 - it decided to commence the analysis under Article XI:1 GATT 'since this is the only provision among the ones raised by complainants that deals with trade measures of a substantive nature' ${ }^{33}$ Having found a breach, it the proceeded to dismiss all other claims - under Article X GATT and Articles 1 and 3 of the ILA-on grounds of judicial economy. ${ }^{34}$

The Panel's order of analysis and exercise of judicial economy were not appealed, depriving the $\mathrm{AB}$ of the possibility to formally reject the approach. That, however, did not stop the AB from expressing rather harsh criticism. Assessing the compatibility of the DJAI with Article XI:1 GATT irrespective of whether it constitutes an import license did not, according to the $\mathrm{AB}$, 'contribute either to the clarity of its reasoning or to a clear understanding of the relationship between different obligations under the GATT 1994 and the Import Licensing Agreement'. ${ }^{35}$ For good measure, it added a footnote recalling the second principle:

Similarly to these disputes, complainants in EC-Bananas made claims under provisions of the GATT 1994 and the Import Licensing Agreement. In that case, the Appellate Body considered that a panel should apply first the agreement that 'deals specifically, and in detail', with the matter at issue. As the Panel's decision to start its examination with the claims under Article XI:1 is not appealed, we neither endorse nor reject the Panel's approach in this regard. ${ }^{36}$

This seems about as far as the AB could go in rejecting the Panel's approach short of the possibility of an explicit reversal. Mavroidis draws the lesson from the AB's dictum as follows:

Panels should from now on, when facing challenges against import licensing regimes, examine the consistency of the challenged measures with the ILA, and not with Article XI:1 of GATT anymore. The purpose of the disciplines embedded in the ILA is to ensure that no restrictions should be imposed through these measures additional to whatever is required to establish a functioning licensing

30 Appellate Body Report, European Communities-Regime for the Importation, Sale and Distribution of Bananas, WT/DS27/AB/R, para. 197 (EC-Bananas III).

31 Ibid., para. 204. See generally, e.g., Chase (2012).

32 Panel Reports, Argentina-Import Measures, para. 6.350, sic.

33 Ibid., para. 6.361.

34 Ibid., paras. 6.480-6.543.

35 AB Reports, Argentina-Import Measures, para. 5.253.

36 Ibid., fn 666. 
regime. Failure to meet the statutory requirements of the ILA would thus amount to the imposition of an impermissible quantitative restriction. Under the circumstances, there will be no need to find that a measure that violates the ILA also violates Article XI:1 of GATT as well. ${ }^{37}$

This solution would save the ILA from obscurity and redundancy. Since challenges on import measures are almost invariably brought against substantive conditions as well as the procedures through which these are enforced, Panel practice has been to examine these measures under the GATT first and to ignore ILA claims later in the exercise of judicial economy. ${ }^{38} \mathrm{De}$ facto, then, the ILA would be brought to life only in case of a challenge against an import licensing procedure that is used to administer an underlying rule, which itself is GATT-consistent. If only because of the political economy of WTO litigation, it is hard to envisage such a case being brought.

And yet, the Appellate Body seems to have made rather more of its own reasoning in EC-Bananas III than it can bear: there, the AB did not really consider the relationship between the ILA and 'provisions of the GATT', but only between the ILA and Article X: 3(a) GATT, which it held to have 'identical coverage'. ${ }^{39}$ To say that the ILA is lex specialis to Article X GATT does not obviously mean that Article X GATT-as-specified-and-detailed-by-the-ILA is lex specialis to Article XI and other provisions of the GATT. ${ }^{40}$ It is, moreover, one thing to say that the more specific and detailed of two provisions with identical coverage should be applied first, it is quite another to say that panels should first apply provisions which cover only the procedures of import licensing and then ignore the substantive conditions attached to licensing under the principle of judicial economy.

It seems clear from its report that the Appellate Body sees the problem, and has a rather more convoluted solution in mind than Mavroidis's crisp conclusion would account for. In the paragraph immediately preceding its criticism of the Panel's approach, the $\mathrm{AB}$ made some 'preliminary observations', expressing apparent discomfort with the fact that the Panel failed to unpack the DJAI:

[T] he panel did not clearly express a view on either which elements of the DJAI procedure correspond to which types of measures, or whether individual elements of the DJAI procedure could be assessed separately. To some extent, the Panel's

37 Mavroidis (2015: 81).

38 See, e.g., Panel Report, Canada-Measures Affecting the Importation of Milk and the Exportation of Dairy Products, WT/DS103/R, para. 7.157 (Canada-Dairy) (breach of Article II GATT, no need for ILA), and Panel Report, Turkey-Measures Affecting the Importation of Rice, WT/DS334/R, para. 7.301 (Turkey-Rice) (breach of Article III GATT, no need for ILA).

39 Appellate Body, EC-Bananas III, para. 203.

40 See, e.g., Panel Report, Indonesia-Certain Measures Affecting the Automobile Industry, WT/DS64/ R, para. 14.152 (Indonesia-Autos) (breach of Articles I and/or III GATT, no need for analysis under Article X GATT). 
reticence to do so may be attributable to the way in which the parties presented their arguments. That is, none of the parties sought to separate and distinguish the different elements composing the DJAI procedure, including any of those possibly relating to import licensing procedures, underlying measures restricting the importation of goods, the discretion granted to certain Argentine agencies, particular formalities or requirements in connection with importation, or the TRRs measure. ${ }^{41}$

It seems, then, that the AB's solution is to compensate for its stance on the lex specialis principle by recalibrating two other tenets of WTO law. First, Panels are to take a rather more critical view of the way complainants decide to describe the measures they are challenging. Not unusually, the Panel had relied on Canada-Wheat Exports and Grain Imports where the Appellate Body stated that 'Panels are free to structure the order of their analysis as they see fit', and '[i]n so doing, panels may find it useful to take account of the manner in which claims are presented to them by a complaining member'. ${ }^{42}$ This much quoted passage may have been rather imprudent, but it was followed by a stern admonition - one that panels are far less keen on quoting - that 'at the same time, panels must ensure that they proceed on the basis of a properly structured analysis to interpret the substantive provisions at issue'. ${ }^{43}$ In casu, the $\mathrm{AB}$ would apparently have expected the Panel to separate procedural issues from the substantive requirements of the DJAI, and to proceed to analyse the first category under the ILA and the second under Article XI:1 GATT, in as far as the latter category comprises anything different from the measures already dealt with under the TRR analysis. The only way to make that scheme work is, of course, for panels to refrain from exercising judicial economy - the second tenet of WTO law under pressure from the lex specialis principle - on the grounds that either analysis makes the other irrelevant. ${ }^{44}$

If this analysis is correct, and the $\mathrm{AB}$ really wanted to launch a new, fine-grained, layered mode of analysis of the ILA and the GATT, then it probably could not have chosen a worse case than this to do so. It is laudable that the AB does not want to bury procedure in substance, or hide substance behind procedure. But the AB's advocated approach of separating and distinguishing between the two, and of assessing them separately, is not obviously very useful in a case where, as with the DJAI, the restriction is largely a function of the absence of underlying rules.

41 AB Reports, Argentina-Import Measures, para. 5.252.

42 Appelllate Body Report, Canada-Measures Relating to Exports of Wheat and Treatment of Imported Grain, WT/DS276/AB/R, para. 126 (Canada-Wheat Exports and Grain Imports).

43 Ibid., para. 127.

44 The $\mathrm{AB}$ noted, for no apparent reason, that 'none of the participants has appealed or called into question the panel's exercise of judicial economy with respect to the claims against the DJAI procedure under the Import Licensing Agreement' (Ibid, fn. 685). 


\section{Economic analysis}

\subsection{Examples of restrictive TRRs}

According to the complainants, the requirements imposed on importers and other economic operators as a condition to import into Argentina are reflected in the agreements negotiated between the Argentine government and the respective importers or economic operators, or in letters addressed by the importers or economic operators to the Argentine government, which describe the specific commitments. The Panel requested the parties, on several occasions, to provide copies of these agreements and letters on which the complainants relied.

The complainants argued that Argentina was in possession of the agreements and letters and was in a better position to provide them to the Panel. All the complainants indicated, as a reason to refrain from providing the copies of the agreements and letters requested by the Panel, that the importers and economic operators that are signatories of these agreements and letters had not authorized the complainants to provide copies to the Panel. They also stressed that, given the discretionary nature of Argentina's import system, the importers and economic operators feared retaliatory actions from the Argentine government, including concerning pending or future import applications, if their identities are disclosed. ${ }^{45}$

However, the complainants submitted to the Panel hundreds of exhibits supporting the existence of agreements between the Argentine government and the foreign companies and operators. These exhibits include, inter alia, copies of domestic laws, regulations, and policy documents; communications addressed to Argentine officials by private companies; statements by Argentine officials and notes posted on websites of the Argentine government; articles in newspapers and magazines; statements by company officials; data from industry surveys; and reports prepared by market intelligence entities.

In this section, we provide examples of the various restrictive TRRs imposed by Argentine authorities. These are taken from the exhibits submitted to the Panel by the complainants.

\section{One-to-one requirement}

Many economic operators have been required to compensate imports annually with exports of at least the same value, thereby achieving a trade balance, as a condition to import.

\footnotetext{
45 Few producers will speak on the record for fear of reprisals. The Argentine media reported cases of the national tax agency using investigations as both a threat and a punishment against those who criticize the government. 'Business owners who complain publicly may suffer the wrath of Fernández, who occasionally interrupts her nationally televised announcements to call out whiners'. ('Argentina's International Trade Disaster', Bloomberg, 8 November 2012).
} 
There are many examples of car manufacturers that started operating in sectors outside their normal business activities as a result of this requirement. ${ }^{46}$ For example, the local Porsche importer agreed to export olives and Malbec wine. Other car manufacturers cut similar deals: BMW started exporting upholstery leather, car parts, and processed rice; Nissan became an exporter of soy flour, soy oil, and biodiesel; Mitsubishi of animal feed, peanuts, and premium mineral water; Hyundai started exporting peanuts, wine, biodiesel, and soy flour; Subaru, agreed to export chicken feed. Other automakers that agreed to offset their imports with exports include Fiat, KIA, Renault, Volvo, and Ford.

Other industries were also affected by the one-to-one requirement. For example, Pirelli was required to export $\$ 100$ million worth of honey to import its tires; motorcycle producers Harley Davidson became a wine seller; and sporting equipment producer Nike started exporting furniture.

\section{Local content requirement}

Certain economic operators have been required to reach a higher level of local content in their products by substituting imports with goods produced in Argentina. The Argentine government stated that import substitution is a state policy and one of the main tools to reindustrialize the country. It has referred to this objective in numerous statements, as well as in its Industrial Strategic Plan 2020. ${ }^{47}$

The local content requirement has been applied to producers in many other sectors. For example, in 2009 the Argentine government adopted a legislation requiring producers of motorcycles to substitute imported parts to a level of $30 \%$ of the unit value of production. In June 2011, the Ministry of Industry required motorcycle manufacturers either to produce motorcycles with at least one-half domestic motorcycle parts or to assemble two motorcycles in the country for each imported motorcycle. ${ }^{48}$ The Argentine government also urged car manufacturers to achieve a larger integration of domestically produced parts and a greater development of national suppliers. It reached agreements with certain car manufacturers whereby they committed to produce certain car models in Argentina and increase local content in their production processes. For example, the 'Ministry of Industry, Giorgi and Moreno agreed with automakers, auto part producers and steel makers to substitute imports of special steels' ${ }^{49}$

46 Exhibits JE-396/EU-82, JE-1 and JE-398/EU-84, among others.

47 The PEI 2020 refers to 11 working groups in the following sectors: leather and footwear; wood; textile and apparel; automotive and auto parts; construction materials; software; agricultural machinery; medicines for human consumption; capital goods; poultry, pork, and dairy products; and chemicals and petrochemicals.

48 Exhibits JE-553/EU-239 and JE-551/EU-237.

49 Exhibit JE-231. 
Other sectors affected by the local content requirement include agricultural machinery, electronic products, the pharmaceutical sector, and the bicycle sector.

\section{Import reduction requirement}

The Argentine government has required certain economic operators to limit their imports (either in volume or in value). This requirement has often been imposed on economic operators along with other TRRs, such as the one-to-one requirement or the local content requirement.

Many operators committed to restrict their imports into Argentina, including automobile and motorcycle producers and importers, supermarket chains, producers of pork products, and producers of electronic and office equipment. For example, in 2011, economic operators in the automobile and motorcycle sectors were required to reduce their imports by $20 \%$ and $40 \%$ respectively. In December 2013, the Minister of Industry reached an agreement with car manufacturers and importers to reduce their imports by around $20 \%$ in value in the first quarter of 2014. This was an average for the sector; the actual percentage of import reduction varied depending on the trade balance of each car manufacturer or importer (see Exhibit JE-477/EU-163 for examples of import reductions in the automotive sector).

\section{Investment requirement}

In some instances, the Argentine government has required companies to make or increase investments in Argentina. This requirement is usually linked to the oneto-one requirement ${ }^{50}$ or to the local content requirement ${ }^{51}$.

There is evidence that economic operators in the automotive sector have been required by the Argentine government to make investments related to their manufacturing output, in order to increase existing levels of production or produce new models in Argentina. Companies that agreed to make these types of investments include Fiat, Renault, Nissan, General Motors, Alfa Romeo, Subaru, Honda, and Hyundai.

\section{Non-repatriation requirement}

The Argentine government has required certain economic operators to refrain from repatriating profits abroad. This TRR has been linked to the one-to-one requirement or to the local content requirement. Examples of these combinations can be found in the agreements between the Argentine government and car manufacturers (e.g., Ford, General Motors, and Peugeot-Citroen), truck manufacturers (e.g., Scania, Renault Trucks, and Volvo Trucks). Agricultural machinery manufacturers and mining companies have also been subject to this requirement. 


\subsection{Evolution of imports of Argentina: much ado about nothing?}

The complaining parties argued that the DJAI and the restrictive TRRs unfairly restricted the importation of their goods into Argentina. Figure 1 below shows the evolution of Argentina's imports from the EU, Japan, and the United States since the establishment of the WTO. ${ }^{52}$

Looking at Figure 1, it is hard to see a clear impact of these measures. The figure shows a drastic drop in imports from the United States and the EU in the early 2000s, corresponding to the end of the fixed exchange rate between the peso and the dollar, Argentina's default on its sovereign debt, and a strong devaluation of its currency. There is a second drop in 2009, which is likely to reflect the Great Recession. ${ }^{53}$

Figures 2 through 4 show the evolution of imports from each of the complaining parties for specific sectors. Again, most sectors experience drastic drops around 2002 and 2009. There seems to be no general pattern within countries across sectors or within sectors across countries.

The fact that we do not see a steady decline in imports from the complaining parties is not surprising, for various reasons. First, the restrictive TRR measures were introduced at different times for different sectors and companies, so we would not expect their effect to kick in at a specific time. Second, small firms may have been forced to stop exporting to Argentina, finding it too costly to meet the requirements imposed by Argentine authorities. ${ }^{54}$ However, large companies were able to continue exporting to Argentina by entering agreements with the government. These firms should not have seen any long-term impact on their exports to Argentina (unless they had to fulfill the import reduction requirement). Given that large firms account for the overwhelming majority of trade flows, we would not expect to see a dramatic drop in aggregate imports. ${ }^{55}$

As we argue below, however, even assuming that the DJAI and the TRRs had no impact on overall imports of Argentina from the United States, the European Union, and Japan, they still imposed large economic costs on the complaining parties (and on Argentina itself).

52 The data used in Figures 1 through 4 comes from the World Integrated Trade Solution (WITS) database.

53 In 2009, the economic decline in world markets met the IMF criteria for being a global recession (a decline in annual real world GDP per-capita weighted). See World Economic Outlook - April 2009: Crisis and Recovery.

54 According to Desarrollo de Negocios Internacionales, a consultancy, 40 foreign companies have left or frozen their operations between 2011 and 2014 ('Foreign firms in Argentina: Waiting for Cristina to go Targeted by the president, foreign companies are leaving or scaling back', The Economist, 13 December 2014.

55 It is widely acknowledged that the firm size distribution is highly skewed (e.g., Axtell, 2001) and that the aggregate trade patterns of an industry can be shaped by the individual behavior of a few firms. For instance, Bernard et al. (2007) report that $96 \%$ of US exports were made up by $0.4 \%$ of US firms. 
Figure 1. Total imports of Argentina from the complaining countries

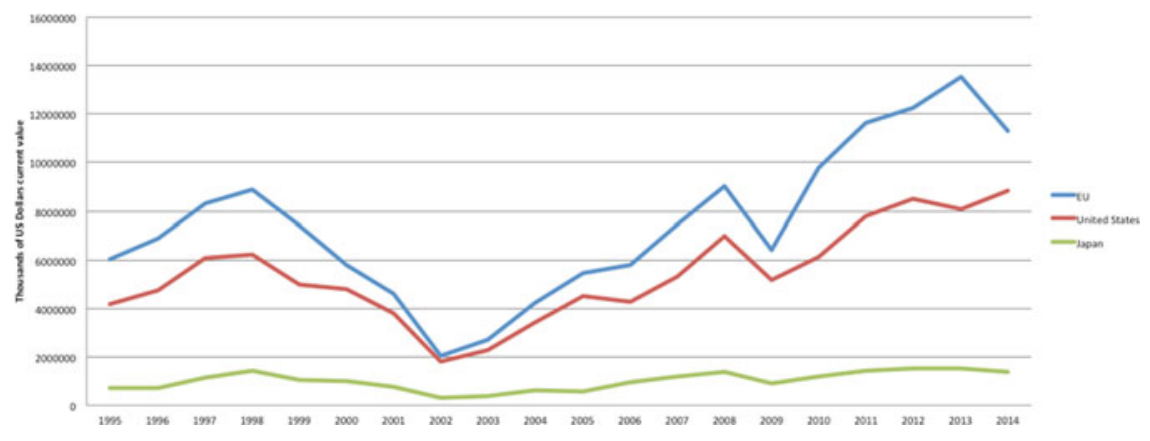

\subsection{Economic costs of the TRRs}

Before reaching an agreement with the authorities to be able to continue importing their goods into Argentina, firms faced substantial uncertainty and delays. For example, early in 2011, Argentina's government decided that car importers would have to match their imports with exports of equal value. For months, car producers and importers tried to figure out a way to comply with this requirement, while their vehicles piled up in customs. According to Argentina's car dealers association, during the first ten months of 2011, BMW sales plunged by half, while hundreds of BMWs were packed at a car port outside Buenos Aires. Businesses complained about the unstable, opaque, and discriminatory business environment.

Recent studies suggest that the uncertainty generated by Argentina's policies can affect firms' entry and investment choices. Handley (2014) shows that uncertainty faced by exporters lowers both the level of product entry and the elasticity of entry to applied tariff reductions. Handley and Limão (2015) provide theoretical and empirical evidence that trade policy uncertainty can significantly affect investments and entry into export markets.

More directly, the conditions imposed by Argentina's authorities distorted the choices of the companies that had to comply with them. As a result, each TRR implied important costs for the firms that were forced to fulfill the requirements in order to continue operating in Argentina.

The one-to-one requirement clearly distorted firms' decisions on their product range. As mentioned in Section 3.1, many companies started operating in sectors outside their normal business activities as a result of this requirement. For instance, companies from the automotive sector started to export peanuts, water, wine, soy products, and rice. The evidence on record shows that there are three main ways for economic operators to increase exports so as to comply with the one-to-one requirement. First, an economic operator may use an exporter as an intermediary to sell products to a buyer in a third country (exportation 'por cuenta y orden'). 
Figure 2. Imports of Argentina from the United States, by sector

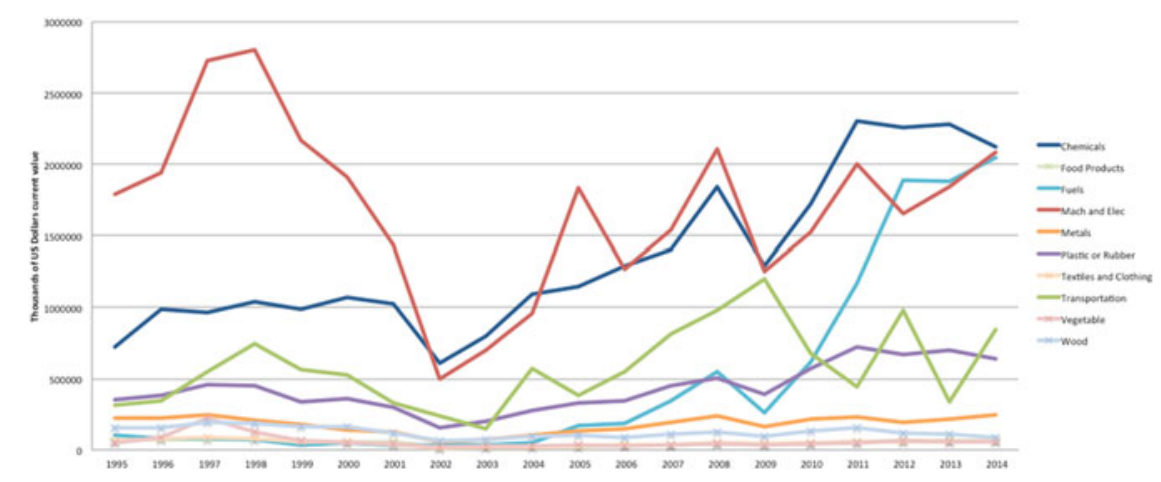

Figure 3. Imports of Argentina from the European Union, by sector

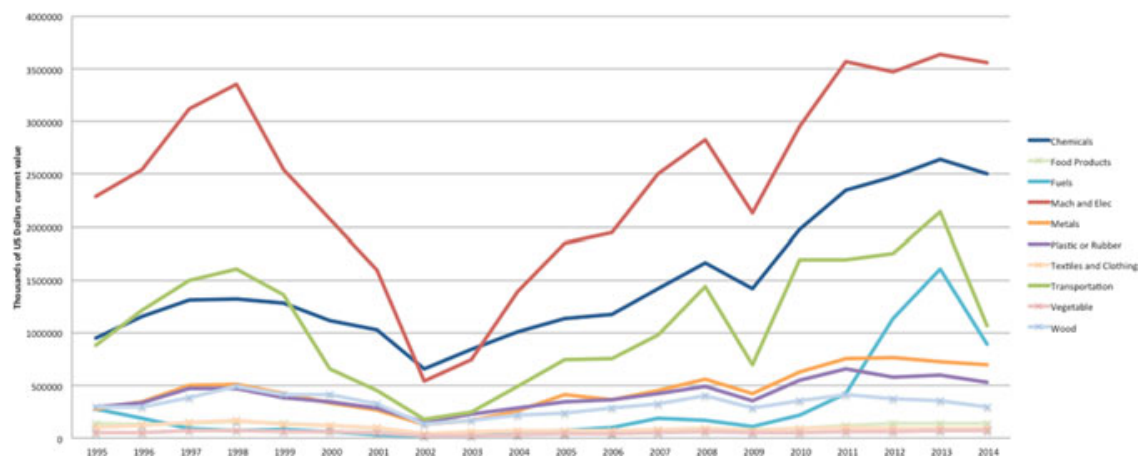

Note: Based on EU 15 countries (countries that joined the European Union before 1995): Austria, Belgium, Denmark, Finland, France, Germany, Greece, Ireland, Italy, Luxembourg, Netherlands, Portugal, Spain, Sweden, UK.

Figure 4. Imports of Argentina from the Japan, by sector

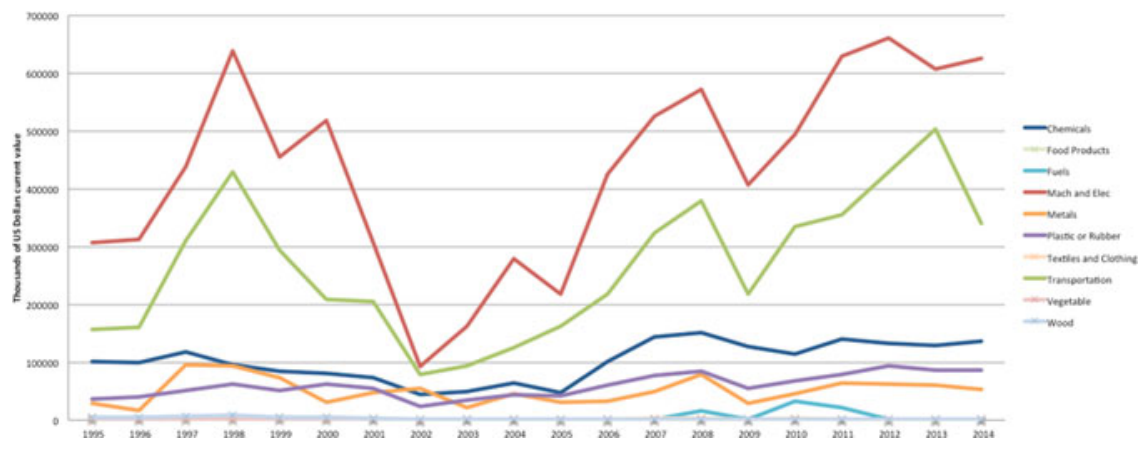


Second, an economic operator may directly export Argentine products that the economic operator (or any other company) produces. And, third, the economic operator may conclude an agreement with an exporter so that the exporter's transactions may be considered as the economic operator's own transactions. ${ }^{56}$

Any of these options may result in additional costs for economic operators. An increasingly large literature shows that multi-product firms dominate exports and that they frequently vary their product mix (e.g., Bernard et al., 2010). Various studies in this literature emphasize that firms have a 'core competence' and show that competition leads companies to become 'leaner and meaner', dropping some of their marginal products while expanding sales of their core products (e.g., Eckel and Neary, 2010). ${ }^{57}$ These studies suggest that it was very costly for companies to undertake activities outside of their normal business in order to comply with the one-to-one requirement. Moreover, exporters willing to provide these services charge fees to the economic operators in need of achieving a trade balance. Evidence shows that these fees range between $5 \%$ and $15 \%$ of the total value of the export operation.

The local content requirement also distorted firms' sourcing decisions. Recent decades have witnessed the rapid emergence of global value chains. Increasingly, production processes are fragmented across countries, and firms source their inputs from suppliers around the world. As a result, trade in intermediate goods now accounts for as much as two-thirds of international trade (Johnson and Noguera, 2012). It is well known that policies that force companies to source inputs in the domestic market give rise to trade diversion in intermediaries (e.g., Grossman, 1981; Falvey and Reed, 1998; Conconi et al., 2016). Recent studies also suggest that, by distorting sourcing decisions, local content requirements may hinder firm-level and aggregate productivity (e.g., Antràs et al., 2014; Blaum et al., 2013; Ramanarayanan, 2014).

The other three requirements (import reduction, investment, and nonrepatriation) were often imposed along with the one-to-one and local content requirement. These additional conditions distorted firms' decisions in terms of the volume/value of their imports into Argentina and their investment decisions.

56 "The absurdity of this "compensation" system - being beyond requiring businesses to export goods they've never heard of - is that it often doesn't even add new exports. Instead, it creates a kind of international trade three-card monte game. Many importers pay exporters a commission to shift existing exports to their name to make the government think they've compensated for their imports. Says Martín Redrado, president of Argentina's central bank from 2004 to 2010: Exporters are getting about 7 percent or 8 percent for doing nothing, so they are quite pleased' ('Argentina's International Trade Disaster', Bloomberg, 8 November 2012).

57 The concept of the core competence of a corporation is widely used in the management literature, where it has been defined by Schilling (2005) as 'a harmonized combination of multiple resources and skills that distinguish a firm in the marketplace'. It was first introduced in this context by Prahalad and Hamel (1990), who argued that core competencies fulfill three criteria: they should make a significant contribution to the perceived customer benefits of the end product; should provide potential access to a wide variety of markets; and should be difficult to imitate by competitors. 
The TRRs were not only costly for foreign firms, but also for Argentine final good producers, for which importing intermediate goods became much harder. Many Argentine producers had to close plants or suspend production because of a foreign parts shortage. For example, Enrique Españon, third-generation owner of Bicicletas Enrique, could no longer import bike parts he had ordered from Shimano, the Japanese bike components maker. This disrupted the firm's production plants for months, until Españon could fulfill the one-to-one requirement by becoming an exporter of 'zaranda' a type of agricultural machinery. In his words: 'The only thing I want to have in my head is making bikes, not doing this other thing ... But whatever, the government asks for it and you do it.' 58

The TRRs also negatively affected Argentine consumers, who lost access to various foreign goods. Many luxury brands closed their boutiques in Argentina because they could not get their merchandise in the country, including Yves Saint Laurent, Ralph Lauren, Hermés, and Calvin Klein. The Argentina-based management of French luxury jeweler Cartier found themselves facing the prospect of having to match in exports all the diamond rings and gold tennis bracelets it imports into the country. Many other foreign goods disappeared from stores or were almost nowhere to be found (e.g., Barbie dolls, Jägermeister, electronic toothbrushes). Apple did not accept the TRRs and as a consequence iPhones and other Apple products became scarce in Argentina. Other shortages were more serious. Medicines and medical devices such as epinephrine auto injectors (EpiPen) grew scarce.

The main beneficiaries of the policies were import-competing Argentine producers, who benefited from the local content requirement and general import substitution policy, and some Argentine exporters who charged high prices to help importers and foreign companies to comply with the one-to one requirement.

\section{Conclusions}

Argentina's experience with 'managed trade' will not go down in the nation's history as a particularly successful episode of economic policymaking. The damage caused to American, European, and Japanese exporters was compounded by the costs imposed on Argentine importers, consumers, and producers sourcing their inputs from abroad. The policy did not even achieve its stated goals of trade balance and import substitution.

As much as offering diplomatic protection to their own exporters having trouble accessing Argentine markets, complainants have in this case acted in favor of unnamed and fearful Argentine economic operators and, perhaps more momentously, they have protected the transparency and predictability and multilateral trade rules. In the process, the Panel and Appellate Body have had to bend 
traditional understandings of trade 'measures' and their application and administration.

\section{References}

Alfaro, L. (2015), 'Sovereign Debt Restructuring: Evaluating the Impact of the Argentina Ruling', Harvard Business Law Review, 1: 47-71.

Alvarez, J. E. and K. Khamsi (2009), 'The Argentine Crisis and Foreign Investors: A Glimpse into the Heart of the Investment Regime', Yearbook on International Investment Law and Policy, New York: Oxford University Press, pp. 379-478.

Antràs, P., T. Fort, and F. Tintelnot (2014), 'The Margins of Global Sourcing: Theory and Evidence from US', NBER Working Paper No. 20772.

Axtell, R. L. (2001), 'Zipf Distribution of US Firm Sizes', Science, 293(5536): 1818-1820.

Baracat, E. A., J. M. Finger, R. L. Thorne, and J. J. Nogues (2015) 'Trade Reform and Institution Building: Peru and Argentina under the WTO', World Trade Review, 14(4): 579-615.

Bernard, A., J. Jensen, S. Redding, and P. Schott (2007), 'Firms in International Trade', Journal of Economic Perspectives, 21(3): 105-130.

— (2010), 'Multiple-Product Firms and Product Switching', American Economic Review, 100(1): 70-97.

Blaum, J., C. Lelarge, and M. Peters (2013), 'Estimating the Productivity Gains from Importing', mimeo.

Chase, C. (2012), 'Norm Conflict Between Covered Agreements-Real, Apparent, or Avoided?', International and Comparative Law Quarterly, 61: 791-821.

Conconi, P., M. García-Santana, L. Puccio, and R. Venturini (2016), 'From Final Goods to Inputs: The Protectionist Effect of Rules of Origin', CEPR Discussion Paper No. 11084.

Eckel, C. and J. Neary (2010), 'Multi-product Firms and Flexible Manufacturing in the Global Economy', Review of Economic Studies, 77(1): 188-217.

Falvey, R. and G. Reed (1998), 'Economic Effects of Rules of Origin', Review of World Economics, 134: 209-229.

Grossman, G. M. (1981), 'The Theory of Domestic Content Protection and Content Preference', Quarterly Journal of Economics, 96: 583-603.

Handley, K. (2014), 'Exporting Under Trade Policy Uncertainty: Theory and Evidence', Journal of International Economics, 94(1): 50-66.

Handley, K. and N. Limão (2015), 'Trade and Investment under Policy Uncertainty: Theory and Firm Evidence', American Economic Journal: Economic Policy, 7(4): 189-222.

Johnson, R. C. and Noguera, G. (2012), 'Accounting for Intermediates: Production Sharing and Trade in Value Added', Journal of International Economics, 86(2): 224-236.

Mavroidis, P. C. (2015), The Regulation of International Trade, Volume 1: GATT, Cambridge, MA: MIT Press.

Prahalad, C. and G. Hamel (1990), 'The Core Competency of the Corporation', Harvard Business Review, 68(3): 79-91.

Ramanarayanan, A. (2014), 'Imported Inputs and the Gains from Trade', mimeo.

Schilling, M. A. (2005), Strategic Management of Technological Innovation, New York: McGraw-Hill/ Irwin. 